\title{
CITIZENSHIP DILEMMA FOR INDONESIAN DESCENT IN SOUTHERN MINDANAO
}

\author{
${ }^{1}$ Hafidz R.T, ${ }^{2}$ Ahmad Baidawi \\ ${ }^{1}$ Mahasiswa Master of International Relations, Monas University, \\ Australia \\ ${ }^{2}$ Prodi Ilmu Pemerintahan, Universitas Jambi, Indonesia \\ Email: ahmad.baidawi@unja.ac.id
}

\begin{abstract}
Abstrak
Adapun tujuan dari penelitian ini adalah untuk mengetahui bagaimana peran pemerintah Indonesia dalam menangani dilema masyarakat keturunan indonesia yang tinggal di mindanao selatan filipina. Seperti yang kita ketahui, ada Lebih dari 8.000 orang keturunan Indonesia yang telah tinggal di Mindanao Selatan, Filipina. Adapun status mereka selama ini secara formal adalah "tanpa memiliki identitas kewarganegaraan" dengan menerima konsekuensi: tidak akan mendapatkan bantuan secara ekonomi dan terpinggirkan secara sosial. Sejauh ini, kebanyakan dari mereka adalah terdaftar sebagai pemegang sertifikat warga Asing Filipina, sehingga mereka dapat menikmati fasilitas sosial dari pemerintah Filipina. Sedangkan yang memiliki paspor Indonesia, akibatnya, mereka akan kehilangan dukungan itu. Adapun Penelitian ini menggunakan metode kualitatif dan pendekatan desktriptif yang didukung dengan data yang berkaitan dengan dilema masyarakat keuturunan Indonesia yang tinggal di mindanao selatan filipina. Hasil penelitian ini menunjukkan bahwa Pemerintah Indonesia dalam menangani masalah diatas tersebut dengan mengorganisasikannya kedalam Diaspora Indonesia dan kemudian meningkatkan status mereka menjadi (Warga Negara Indonesia Terdaftar). Pada 2018, pemerintah Indonesia telah mulai mengeluarkan paspor Indonesia untuk mereka. Namun demikian, di balik penyelesaian hokum diatas, banyak dari mereka khawatir tentang konsekuensi ekonomi dan sosial yang akan mereka terima. Oleh karena itu dalam lima tahun ke depan mereka akan menghadapi persimpangan yang menentukan: Kembali ke Indonesia dalam ketidakpastian atau tetap tinggal di sana sebagai warga negara Indonesia di luar negeri dengan biaya yang membebani. Mengenai situasi dilematis ini, pemerintah Indonesia mencoba mengadopsi pendekatan yang lebih inovatif dan
\end{abstract}


komprehensif dalam hukum, sosial, budaya, dan ekonomi juga dalam program pemberdayaan sosial yang terintegrasi. Sehingga dilema masyarkat keturunan Indonesia yang ada di Mindanao bisa mendapatkan kepastian.

Kata kunci: Indonesia Diaspora, RINs, Pemberdayaan Sosial.

\section{A. INTRODUCTION}

The origin of Indonesian people ${ }^{1}$ who has been living in Southern Mindanao, the Philippines, could be dated back to the 17th Century. According to Shinzo Hayaze, the first wave of the migration happened between 1675 to 1775 when people sailed away from their povertystricken, neglected, and volcanic homeland Sangir and Marore island ${ }^{2}$, and began to settlein Southern Mindanao (Talampas, 2015, p. 140). The second wave of migration happened by the end of 19th Century. According to Alex Bacarro, the counsel for the Philippine Justice Department's Refugee and Stateless Persons Unit, the present Indonesian descents have already come to the Philippines since 1874 (Espina-Varona, 2016). More comprehensively, Manigbas lists a wide-range timeline of Indonesian migration to Southern Philippines, and notes that there were two factors causing more than ten thousands of Indonesian people migrated to Mindanao (Manigbas, 2018): First, as a push-factor, was the impact of bloody communist purge in 1950, and the second, as the pull-factor, was the economic opportunities in Mindanao under the United States post-colonial rule.

Nevertheless, the problem of nationalities for the settlers had already begun soon after the independence of the Philippines in 1942 followed by Indonesian proclamation of independence in 1945. According to Indonesian legal system, the act of Citizenship of the Republic of Indonesia (Law No 62/1958) that has been renewed by the Act of Citizenship (Law No 12/2006) mentions thatany person who would like to apply to become

\footnotetext{
${ }^{1}$ By that time, Indonesia was called "Oost-Indische” (East-India) under the Dutch colonial rule.

${ }^{2}$ Present day Sangihe and Talaud Island, North Sulawesi (Celebes).
} 
Indonesian nationality mustbe "born within the territory of the Republic of Indonesia, or at the time of submitting an application to reside in Indonesian soil for at least the last 5 consecutive years or at all for 10 non-consecutive years." According to the regulation above, obviously, the Indonesian descent who had been living abroad in Southern Mindanao had lost their Indonesian citizenship, even thoughthey still self-identified as Indonesian.

Meanwhile, they also did not meet with the Philippines law of citizenship, both by the principle of jus sanguinis and jus soli.The Philippines government could not recognize them with jus sanguinis because they were not born by Filipino parents, also could not with jus soli, because they were not born in the Philippine soil. Facing the statelessness, added with lack of information, uneducated condition, and living in poverty, the Indonesian descents were trapped into a legal limbo.

By 1990, the Indonesians society that lived in Philippine already got encouraged to register with the Philippine Immigration authorities formally. Based on the law in the Philippines that is valid since the Memorandum Order of the Commissioner of Immigration No.32/April 26/2002, all foreigners that have turned to 14 years of age or more should pay for the Alien Certificate of Registration (ACR) and all foreigners that have lived for more than fifty-nine days need to have an Alien Certificate of registration which should be renewed annually(Putri, 2013).By 2012, the Philippines and the Indonesian government started their programs to take action to address the status of the Indonesian society related with the UNHCR's Ibelong campaign that aims to end statelessness all over the world by 2024 (Manigbas, 2018).

The Indonesian government handles the problem of the statelessness by doing a program to register all the Indonesian descents in the entire Mindanao region. The Indonesian government tries to collect data of the Indonesian society in the entire Philippines. The Society that has been registered by the government of Indonesia is included in the Program from the Consulate General of Indonesia in Davao that was coordinated with the 
United Nations High Commissioner for Refugees (UNHCR) that was created in 2012.

The Philippines' Department of Justice (DOJ) with the Consulate General of Republic Indonesia in Davao City with the support of the Philippine Public Attorney's Office (PAO) and the Bureau of Immigration (BI) work together to register all the Indonesians society in the Philippines and have succeed to register 8,745 persons of Indonesian Descent (PIDs). They settle in seven provinces and two cities:Provinces Del Sur, Davao Oriental, Sarangani, Sultan Kudarat, South Cotabato, North Cotabato, and the city of General Santos and Davao. A statement from UNHCR said that 566 persons of Indonesian descent had been confirmed as Filipinos and the rest choose as Indonesian (Manigbas, 2018).

In the next sequence, since November until December 2016, Indonesian government has given the citizenship status to 2,399 Indonesian descent who live in Southern Mindanao, the Philippines after living in stateless status for relatively long time. Indonesian government gave the status to the Indonesian people during the averment mission of the Indonesian Citizenship that has been done through the Consulate General of Indonesia that conducted this program through a cooperation with the technical team set up by Indonesian Ministry of Law \&Human Rights and the UNHCR.

The further action of Indonesian government to eradicate the statelessness of the Indonesian descents is delivering the "SPKRI" stand for "Surat Penegasan Kewarnegaraan Republik Indonesia" (document of affirmation as Indonesian citizen). By January 3rd2018, Indonesian government proceeded to the next action by giving 300 passports to the Indonesian descents. H.E. Retno Marsudi, Indonesian Minister of Foreign Affairs,handed over the passports in a special ceremony located in the Indonesian Consulate office in Davao City. (Hassan, 2018).

In one hand, the passport procurement is legal and formal settlement to the status of the Indonesian descents in the Philippines. The program is 
profitable to both Indonesian and the Philippines government. On the other hand, there are reluctant responses from several figures of Indonesian descents in Southern Mindanao. Some of them are Mr. Sam Macpal (known as Mr. Sammy) and Mr. Benny Makatilu Takatalide (known as Mr. Benny). For years, these figures act as "pamong" and "penghubung" (liaison officers) who responsibleto connect between the Consulate General of Indonesia in Davao City and the Indonesian descents in Glan Municipality. They said that beyond a legal standing, the passport possession could create future problems, both socially and economically. As a passport holder, Indonesian descents will lose the rights they enjoy as the ACR holder, like health facilities and education for their children. Having a passport will enforce them legally to be treated as full foreigners who oblige to pay a lot for visas and other expenses. Dealing with their current economic condition, the passport ownership is dilemmatic for them. ${ }^{3}$

\section{B. RESEARCH METHOD}

This paper is based on the research aims to explain the reluctance of the Indonesian descents in Southern Mindanao to possess Indonesian passport as legal and affirmative document of citizenship. Using grounded research, the authors made a series of interview with some key figures in the research area. The author visited the RINs who live in Glan municipality, province of Sarangani, because it is one of provinces beside Davao City where most of the PIDs live. The technique of data collection is a combination between secondary data sources and sharing questionnaires for respondents plus elaborative interviews to some key figures. The respondents are totally 96 persons of RIN of various ages, from 18 to 80 years old, and focus the questionnaire sharing and interviews in Barangay (village) of Taluya, Gumasa, Baliton, Burias, and Laensasi.

\footnotetext{
${ }^{3}$ Interview with Mr. Sammy and Mr. Benny, January 27th 2019.
} 


\section{RESULT AND DISCUSSION}

\section{(1) Indonesian Descents: Live between Poverty and Illegality}

Under the Philippines governments, every foreigner that live in the Philippines should have the Alien Certificate of Registration (ACR). Otherwise, the foreign-origin settlers will be considered as the illegal migrant and will quickly get deported back to their origin country. This was one of the first dilemmas that exist to the Indonesian descents during the first and second decades after the Philippines independence in 1946. The ACR is one of requirementsif they want to attend the public school or go to search for work. The schools and companiesusually require the applicants to expose the ACR, except for the informal or lower-level job such as plantation labor, small-scale peasant labor, or small-scale fisherman.

Without the ACR, they will face unstable source of income as peasant or fisherman. As foreigners, they cannot own the land, so they must rely on the land for rent to cultivate. Of course, it places the Indonesian descent in a difficult and costly position. Some of them, as Mr. Benny did, married to a Filipino woman, so he can be a peasant cultivating his wife's land. On the other side, as fisherman, the Indonesian descents should live nearby the coast to get easy access to the sea. However, without the land ownership, they just rely on the permission from the coastal area owner to build their cabin for staying and parking the boat. Once the owner wants to convert the coastal land use ${ }^{4}$, the Indonesian descent family cannot do anything to defend, except moving to the other part of the coastal land or into more distant area from the coast. In an interview, Mr. Sammy Macpal explained that during the last five years, the coastal area in Sarangani have been developing into recreation destination. There are more and more tourism accommodation facilities, like hotels, restaurants, and recreation beaches along the coastal land. Time by time, it obviously

${ }^{4}$ Interview with Mr. Sammy Macpal, January 27th, 2019. 
narrows the access for the fisherman. To anticipate the hard life situation, the Indonesian descent attend to some informal occupations like taxi driver, "sikat" driver, or selling things in a small home-based stall, and the other kinds of micro-scale economies. In general, the Indonesian descents are living in a subsistence economic condition.

The other situations are in terms of security and education. Sometimes, the security aspect must be considered the most, especially when the Philippines government operates the legal enforcement, whether regularly or during the pursuit of a suspect of illegal immigrant ${ }^{5}$. Once Indonesian descent is founded without any legal documents, especially ACR,he/she will be deportedback to Indonesia or put in first in the immigration detention. In terms of education, the ACR also becomes the essential documents. The foreigner that live in the Philippines cannot attend to school without ACR. Even though, some schools in Glan,Sarangani, apply individual discretion for the Indonesian descents or their children who has no ACR. However, that is not in all schools in Glan, Sarangani.

\section{(2) The Dilemmas during five-year opened window.}

The first dilemma is dealing with the legal matter. The government of the Philippines under the Department Circular no 026 have issued Guidelines on the Issuance of Special Non-Immigrant Visas under section 47 (A) 2 of Commonwealth Act No.613, as Amended to the RINs. This policy is good in its first place. However, it has a further problem since the free visa will be expired in the next five years. It means, five year ahead,the visa holder needs to renew with regular visa which is not free and even quite expensive for the

\footnotetext{
${ }^{5}$ An interview with Capt. Joyce, the Head of Immigration office in Glan Sarangani. The immigration officer said that because of the porous border area among Southern Philippines, North Sulawesi/North Kalimantan and Sabah Malaysia, sometimes illegal immigrants arrived to the Philippines through the coastal area of Glan Sarangani.
} 
PIDs. It needs P8,000 (USD 153) per year and P3,000 (USD 57) per five years expenses. ${ }^{6}$

Furthermore, as Indonesian passport holder, the RINs must prepare another P 1,500 (USD 29) to renew the passport.To the RINs who most of them are in subsistence economy, the cost of the visa renewal is obviously burdensome. Instead of the above costs, most of the RINs are difficult to pay USD 50 per five years for the renewal of ACR, exclude the expenses of travel and the other accommodation costs. $^{7}$

Therefore, even though it is still free during the next five years, however, it must be monitored and anticipated by Indonesian diplomats to prepare for the worst incoming risks. Compare to their average income, they face the dilemma between cost-efficiency and the risk of deportation.

The policy of the passport issuance from the government of Indonesia is a good deal to give the legal status to Indonesian descents. Until recent times, the ACR is the only legal paper they have. So far, it is enough to cover the basic social facilities in the Philippines such as basic educations and health services. However, the Philippines government requires passport to the foreigner who want to attend higher education. In this context, the passport ownership is a chance to increase the education status of the Indonesian descents. Therefore, in turn, there will be wider opportunities to improve their quality of life in general. However, the passport ownership is like a double-edge sword, depends on their economic condition during the next five years.

The author believes that the problem from Indonesian descents after the distribution of passport are several. The Registered Indonesian Nationality that lives in the Glan commonly are the people

\footnotetext{
${ }^{6}$ Interview with Mr.Galih Perdana, the Head of Immigration Office in the Indonesian Consulate General, January $28^{\text {th }}, 2019$.

${ }^{7}$ Interview with Mr. Drickson Adilang, a RIN, January 27th, 2019.
} 
that live below the poverty line. Commonly the problem that the author believes will be the dilemma of the passport holder would be in term of, so they could renew the passport after the passport expired. The dim prospect is reflected in an interview with Mr. Omar, a RIN. He believes that it would be burdensome for the Indonesian descents. Instead of paying for passport renewal, there are many Indonesian descents even unable to pay for ACR.

According to Mr.Drickson Adilang, a RIN, before the distribution of passport in 2018, the people of Indonesian descents that live in the Mindanao were safe even though they do not have passport. They are required to just own an ACR and because they could speak on the native language of the Mindanao like Visaya Language, Maguindanao, and Tagalog and that is one the reason they are still safe because they could communicate with the local people easily and except they meet the person in charge of their legal documents, commonly they will not get question about their citizenship status. The faces and the shape of the body that also comes from ASEAN make a face from the Indonesian descents, and the Local Philippine people are a look alike.

The Indonesian descents also need to pay I-card after the policy from Indonesia will be Implemented and which policy it is. Under the act of Immigration of the Philippines number 47(a) 2 the Person of Indonesian descents that were born in the Philippines and called as the native-born and still maintained their citizenship as Indonesian need to pay the ACR since 6 August 2018 they need to pay 50 dollars per 5 years to pay that and they do not need to Pay ACR anymore because the number of their ACR will be put on their I-Card and it means the Indonesian descents will need Visa which is in this term for 5 years they will have special non Immigrant Visa for 5 years because of the Indonesian and the Philippines Joint Commission decision but after 5 years they should already pay regular visa whether it is student visa, 
tourist visa or working visa. Thus, It means they need to pay more 1500 dollars and 50 Dollars for I-Card and also living permit for 1 one until five years and in this term called Alien Employment Permit that takes cost P8000 Per years and by this number that they should pay, the Person of Indonesian descents if failing to improve their living qualities to increase the salary per month or per years so they can have much money to pay their legal documents obligation, they will undoubtedly face the big trouble in the next 5 years after the Passport already expired.

The actions from the Government of Indonesia to distribute a passport and free visa have already in-line with the Keohane theory of Legalization because it will give the concept of the obligation, legalization, and precision and it means to make the Indonesian descents that before that live without obeying the International and domestic law from Indonesia and The Philippines will make them involved with it and will make them also live as they should be as the Indonesian citizen that live outside the Jurisdiction of Indonesia.

This paper has also found the theory of structuration from Anthony Giddens that both of the Agent and structure influence each other is right. The government of Indonesia and The Philippines Government are the structure, and the Agent is Indonesian descents. The process of the Legalization from the Indonesian government have taken because the Indonesian descents felt that they need to be legal because without any legal documents they will live in very vulnerable and not stable situation because they could quickly get deportation if they don't have any legal papers that make them allow to live in the Philippines.

The dilemma comes up because the distribution of passport and visa give them a huge thing to think and to accomplish in the next following years because after the passport and visa already expired they need to renew it and it will take much money. The status quo of 
the occupation of the Indonesian descents are consider is not quite right because most of the Indonesian descents live as the farmer and fisherman that cannot have a stable situation of source of Income, and it makes them get dilemma indeed because before the distribution of passport they commonly only pay Alien Certificate of Registration that only cost P.160 per year but most of them cannot pay it. Compare to the passport that will take them P.1500 per 5 years, of course; it is huge of a gap between the Alien Certificate of Registration and the price of a passport.

The Indonesian descents that live in the Philippines are almost impossible to get a job in the public office or in the Philippines companies. ${ }^{8}$ During the interview, Mr. Sammy Macpal also explained that most of the Indonesian descents who become labors in copra farmsusually earn only about a third of the formal wage rate. ${ }^{9}$ Their relatively lower-level income place them in a subsistence, even poor, economic condition.

Since they cannot attend the proper education to find a better job, they fall into economic and social limbo. This chapter would like to conclude the dilemma that the Registered Indonesian Nationalities are facing. First, they will be lost all of the health-care and educational support from the Philippines government, and it means they will pay the health cost just without any subsidy anymore, and they will not get any education support that makes them could get to the school by free, and we can see from that it is, of course, a dilemma from them. In another side, the price of passport that they should pay and also visa in the next following years will be a big problem if they cannot overcome it whether they want it or not they if they want to still live in the Philippines they need to find the way to renew the Passport and Visa. In another hand, the Registered Indonesia Nationalities are quite

${ }^{8}$ Interview with Mr. Sammy Macpal, January 17th 2019.

${ }^{9}$ In average, the wage rate for Filipino labor is P 9,000 (about 172 USD) a month. Therefore, Indonesian descent labor will earn P3,000 (USD 57.5 USD). The land-owner keep the 2/3 of it. 
difficult to return to Indonesia because they have already strong connection with The Philippines either they have their family cemetery over-there or some of their family already married with the local people.

This research has found that the best way from the Registered Indonesian Nationalities are return-back to Indonesia if they cannot find the way to renew the passport and the visa. Thus, they could live freely and without any insecure to get deportation when they cannot renew the passport and the visa as their existing permit. However, as the Structuration theory means that the agent and the structure are influenced by each other, both of the Indonesian people that choose to return back to Indonesia should also get help from the Government of Indonesia to adjust themselves with the new environment thus, finally, they continue their life in Indonesia without a long time to take to adjust with the new environment. The Indonesian government should take the responsibility to guarantee the safety of the Indonesian citizen living abroad inregards to protect them both politically, economically, and culturally.

The possible anticipative and innovative settlements:

(1) To whom choose to settle in Southern Mindanao, in short-term, by providing subsidy for the expenses in passport renewal, includes fee, transport, and accommodation; In the long-term, Indonesian government must formulate a social empowerment program to improve their economy, so they will be able to pay for their citizenship autonomously.

(2) "Coming home" program to move them to the proper places like North Sulawesi, Gorontalo, and the surrounding island. It recalls the author to the "transmigrasi" (inter-island migration) program under Soeharto regime in 1970 and 1980s. Of course, the "coming home" must be done with full and comprehensive support from Indonesian government. It includeshousing, job 
opportunities, health insurance, and scholarships to support their children's education and life-skills.

This research has found that the best way from the Registered Indonesian Nationalities are return back to Indonesia if they cannot find the way to renew the passport and the Visa, as they could live freely and without any insecure to get deportation when they cannot renew the passport and the visa as their existing permit. However, as the Structuration theory means that the agent and the structure are influenced by each other, both of the Indonesian people that choose to return back to Indonesia should also get help from the Government of Indonesia to adjust themselves with the new environment thus, finally, they continue their life in Indonesia without a long time to take to adjust with the new Environment. The Indonesian government should take the responsibility to guarantee the safety of the Indonesian citizen living abroad in regards to preventing them from creating issues and thus maintain their settlements.

\section{(3) CONCLUSION}

To conclude, this research have found that there are many phenomena that the author has found that during the research that the problem of the Registered Indonesian descents are the problem that commonly the Indonesian people that live in the territory of Indonesia almost do not now that there are many of Indonesian descents that live in the Philippines with very minimum legal documents that they have. The Author has also concluded the process of the legalization from the government of Indonesia from only become the Person of Indonesian descents (PIDs) to finally became registered after the Government of Indonesia Given them "Surat Penegasan Kewarnegaraan Republik Indonesia" for 2425 Indonesian descents. The author found the Government of Indonesia already given 1259 passports for the Indonesian citizen and still half process forgive to all of the Indonesian descents legalization by giving them a passport. 
The author has seen that the dilemma between the legality and welfare commonly came up because after they own the passport and visa, the Registered Indonesian Nationality will be lost several supports from The Philippines government that support their stage of welfare like the support from the education and also health-care programme. Mostly the Registered Indonesian Nationalities are the people that live below the poverty line, and we can see when they lost the support from The Philippines government it means they will live more vulnerable than before. They also need to think about how they should live after become they become a legal citizen of Indonesia.

Started since 1675 the migration of the Indonesian descents from North Sulawesi and surround or at that time still called as Nusantara people have shown the relations between Indonesian and The Philippines have happened since centuries. The migration of the Indonesian descents from North Sulawesi until now still happened based on the last data from consulate general 8745 People register themselves as the Indonesian descents, and more of that probably are not registered in the Consulate General of the Republic of Indonesia. The problem of the Indonesian descents that live in the Southern Mindanao is commonly they run their migration by using pump boat and fisherman boat and do it by using the ancestor route or the black route because of the lack of legal documents that they have to make them will not allow entering the Philippines from the border station. The lack of legal documents from the Indonesian descents makes the Government of Indonesia help them by giving the passport as the action to make them become a legal citizen of Indonesia alongside with also Visa as their existing permit. However, during the research, the writer has found the action from the Indonesian Government to give passport and visa has been giving them a big dilemma to solve. 


\section{REFERENCES}

\section{Journals:}

Alam, M. B. (1980). Contemporary Ideas and Theories of Nationalism. The Indian Journal of Political Science, 1-13.

Coastoworth, J. H. (1996). Welfare. Oxford Journals, 1-12. D.Inglis. (2012). An Invitation to Social Theory, Polity.

Fuchs, C. (2004). Knowledge Management in Self-Organizing Social System. Journal of Knowledge Management Practice.

Talampas, R. (2015). Indonesian Diaspora Identity Construction in a Southern Mindanao

Border Crossing. Asian Studies: Journal of Critical Perspectives in Asia, 131-62.

\section{Books:}

Beth A Simmons, R. H. (2007). International Law and International Relations. Cambridge University Press.

Heywood, A. (2019). Global Politics. China: Palgrave Foundations.

Putri, R. G. (2013). Upaya Kjri Davao City Filipina Dalam Melakukan Legalisasi Terhadap Status Hukum Wni Pemukim Ilegal Di Mindanao Selatan Filipina (2006-2012). Yogyakarta: Universitas Muhammadiyah Yogyakarta.

\section{Official Documents:}

Jacobs, L. K. (2019, January 01). Data of Cross-Borders People from Indonesia to the Philippines. (H. R. Sjahputra, Interviewer)

Majid, A. A. (2016). Registrasi dan konfirmasi kewarnegaraan bagi keturunan warga Negara Indonesia di Mindanao. Davao City: Consulate General Republic of Indonesia.

Subagja, R. (2019, January 13). (H. R. Sjahputra, Interviewer) The government, I. (2016, 12). UNDANG-UNDANG REPUBLIK INDONESIA NOMOR 12 TAHUN 2016. Indonesia: Government of Indonesia.

\section{Websites:}

2.399 Keturunan RI Diberi Status WNI. (2019, January 14). Retrieved from Media Indonesia: 
http://mediaindonesia.com/read/detail/80082-2-399-keturunan-ri-diberi-status-wni Chandra, B. A. (2018, November 02). Pengertian, Fungsi, Jenis dan Syarat Membuat Paspor. Retrieved from Bagi-in.com: https://www.bagiin.com/syarat-membuat-paspor/

Espina-Varona, I. (2016, March 16). Indonesians emerge from legal limbo in the Philippines.

Retrieved from Ucanews.com: https://www.ucanews.com/news/indonesiansemerge-fromlegal-limbo-inthe-philippines/75505

V. Jacobus (2019, January 01). Data of Cross-Borders People from Indonesia to the Philippines. (H. R. Sjahputra, Interviewer)

Firdausi, F. A. (2017, November 3). Tanam Paksa Dorong Penelitian Pangan. Retrieved

https://historia.id/sains-teknologi/articles/tanam-paksa-dorong-penelitian-pangan$\mathrm{P} 7 \mathrm{xVb}$

Hasan, R. A. (2018, January 03). Menlu RI Beri Paspor Untuk 300 keturunan Indonesia di Filipina.

Retrieved from Liputan 6: https://www.liputan6.com/global/read/3214468/menluriberipaspor-untuk-300-keturunan-indonesia-di-filipina. 